Gut, 1984, 25, 57-61

\title{
Vasoactive intestinal peptide concentrations and immunocytochemical studies in rectal biopsies from patients with inflammatory bowel disease
}

\author{
C O'MORAIN, ANNE E BISHOP, G P McGREGOR, A J LEVI, S R BLOOM, \\ JULIA M POLAK, AND T J PETERS
}

Divisions of Clinical Cell Biology and Clinical Sciences, MRC Clinical Research Centre, Harrow, Middlesex, and Departments of Histochemistry and Medicine, Hammersmith Hospital, London

SUMMARY Vasoactive intestinal polypeptide (VIP)-containing nerves and VIP content of endoscopic rectal biopsies from 47 patients with inflammatory bowel disease and 17 normal controls were examined by immunocytochemistry and radioimmunoassay. Immunocytochemistry revealed a consistent increase in, and abnormal appearance of, VIP nerves in patients with Crohn's disease not only those with rectal involvement but also patients with no histological evidence of rectal disease. Normal control biopsies contained $1.64 \pm 0.39 \mathrm{pmol} \mathrm{VIP} / \mathrm{mg}$ protein as compared with $3.43 \pm 1.24 \mathrm{pmol} \mathrm{VIP} / \mathrm{mg}$ protein in tissue from patients with rectal Crohn's disease and $5 \cdot 37 \pm 1 \cdot 23 \mathrm{pmol} \mathrm{VIP} / \mathrm{mg}$ protein in those with Crohn's disease without rectal involvement. Ten of the 17 biopsies examined from ulcerative colitics showed a normal pattern of VIP innervation. Examination of the conventional histology of these biopsies showed that only areas with obvious active proctitis had increased VIP nerves and, unlike the appearance in Crohn's disease, these nerves had a normal morphology. The VIP content of these biopsies was similar to that of the controls; $1 \cdot 34 \pm 0.37 \mathrm{pmol} / \mathrm{mg}$ protein.

Vasoactive intestinal polypeptide (VIP) is a 28 amino acid peptide known to have powerful pharmacological effects on the gastrointestinal tract. ${ }^{1}$ It causes vasodilation, relaxation of smooth muscle, and it stimulates secretion. This latter stimulatory effect on water and electrolyte secretion is clearly shown by the WDHA (watery diarrhoea, hypokalaemia and achlorhydria) or VIPoma syndrome where abnormally high concentrations of circulating VIP cause profuse, watery diarrhoea. ${ }^{23}$

In the human gut, VIP nerves, the most abundant of all peptide-containing gut nerves are found at all levels of the tract and in each layer of the bowel wall. ${ }^{4}$ Previous studies have shown that VIP nerves were hypertrophic in surgical specimens taken at resection for Crohn's disease in comparison not only with normal bowel removed at carcinoma resection or jejunal-ileal bypass, but also with bowel taken

Address for correspondence: Professor T J Peters, Division of Clinical Cell Biology, MRC Clinical Research Centre, Watford Road, Harrow, Middlesex HA1 3UJ.

Received for publication 21 March : 983 from patients with the other inflammatory bowel disease, ulcerative colitis. ${ }^{5}$ A notable feature of this hypertrophy was its consistent appearance in the mucosa and submucosa of diseased specimens. This finding indicated that examination of VIP nerves in endoscopic biopsies may help in providing a differential diagnosis for the two main forms of inflammatory bowel disease, particularly in indeterminate cases where histological and clinical features are not clear cut.

In the present double blind study, immunocytochemistry and radioimmunoassay were used to investigate VIP nerves and VIP content in endoscopic rectal biopsies from patients with Crohn's disease, both with and without rectal involvement, and compare them with those from normal controls and patients with ulcerative colitis.

\section{Methods}

\section{PATIENTS}

A group of 47 patients, in whom rectal mucosa histology was required for diagnostic or follow up 
purposes were studied (Table 1). Endoscopic biopsies were taken from the rectum at a level below the peritoneal reflection. The group was made up of 17 patients attending the gastroenterology clinic for investigation of non-specific symptoms in whom no rectal pathology was subsequently found and 47 patients with some form of inflammatory bowel disease. The diseased biopsies were classified on the basis of clinical and histological findings into three separate groups; 28 from patients with Crohn's disease, 14 patients with disease involving the rectum and showing macroscopic pathology, and 14 with intestinal Crohn's disease diagnosed on clinical and radiological grounds but with no histological changes in the rectum, and 19 patients with ulcerative colitis.

\section{TISSUE PROCESSING}

Each biopsy was processed for immunocytochemistry and radioimmunoassay of VIP content. The biopsy was divided into two. One half was processed for immunocytochemistry by immersion fixation in $0.4 \%$ benzoquinone in phosphatebuffered saline $(0 \cdot 15 \mathrm{~mol} / \mathrm{l}, \mathrm{pH} 7 \cdot 1-7 \cdot 4)$ for 20 minutes. ${ }^{6}$ After fixation the tissue was washed for at least 24 hours in a $7 \%$ solution of sucrose in phosphate-buffered saline. The biopsy was then mounted on a cork mat and rapidly frozen in melting Arcton $\left(-150^{\circ} \mathrm{C}\right)$. Ten micron thick sections were cut in a cryostat at $-20^{\circ} \mathrm{C}$, mounted on poly-L-lysine coated slides and air dried before immunocytochemical and histological examinations were undertaken.

The other biopsy was processed for radioimmunoassay. It was immediately placed in $3 \mathrm{ml}$ ice-cold

Table 1 Clinical details of patients studied

\begin{tabular}{llll}
\hline & Controls & $\begin{array}{l}\text { Crohn's } \\
\text { disease }\end{array}$ & $\begin{array}{l}\text { Ulcerative } \\
\text { colitis }\end{array}$ \\
\hline Number & 17 & 28 & 19 \\
Age & 50 & 44 & 53 \\
(Mean and range) & $(31-76)$ & $(18-80)$ & $(34-73)$ \\
Disease activity Inactive & - & 18 & 11 \\
$\quad \begin{array}{c}\text { Active } \\
\text { Radiological extent of disease }\end{array}$ & - & 10 & 8 \\
Ulcerative colitis Rectum & & \\
\multicolumn{1}{c}{$\begin{array}{l}\text { Left side } \\
\text { Total colonic involvement }\end{array}$} & & 9 \\
Crohn's disease & $\begin{array}{l}\text { Small bowel } \\
\text { Ileo-colonic }\end{array}$ & 4 & 5 \\
$\quad \begin{array}{l}\text { Colonic } \\
\text { Prednisolone }\end{array}$ & 13 & \\
Treatment & 10 & 4 \\
& $\begin{array}{l}\text { Salazopyrine } \\
\text { Prednisolone and } \\
\text { salazopyrine }\end{array}$ & 3 & 6 \\
& None & 4 & 4 \\
& & 11 & 5 \\
\hline
\end{tabular}

cold sucrose $(0.3 \mathrm{~mol} / \mathrm{l})$ containing $\mathrm{Na}_{2}$ EDTA (1 $\mathrm{mmol} / \mathrm{l}) \mathrm{pH} 7.4$ and ethanol $(22 \mathrm{mmol} / \mathrm{l})$ (sucrose medium). The biopsy was then finely minced in a Polytron homogeniser (Kinematica GmbH, Lucern, Switzerland) for 15 seconds at speed setting 2 and disrupted by 10 strokes of a loose-fitting and 10 of a tight-fitting pestle, in a Dounce homogeniser. An aliquot was retained for protein assay and an equal

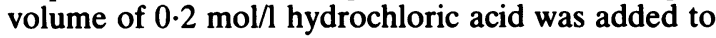
the remaining homogenate and the extract coded and stored at $-20^{\circ} \mathrm{C}$ for subsequent radioimmunoassay.

\section{IMMUNOCYTOCHEMISTRY}

Immunocytochemistry was carried out using the technique of indirect immunofluorescence. ${ }^{7}$ Cryostat sections were incubated with VIP antiserum (dilution 1:2000) for $16-20$ hours at $4^{\circ} \mathrm{C}$ in a moist atmosphere. After thorough rinsing in phosphatebuffered saline, the sections were incubated with fluorescein-conjugated goat anti-rabbit globulin (dilution 1:100) for one hour at room temperature. After this time the sections were again thoroughly rinsed, mounted in phosphate-buffered saline glycerol (1:9) and examined under a Leitz fluorescence microscope. A blind semi-quantitative assessment was made of the VIP immunostaining in each section.

The antiserum to VIP ( 28 amino acids) was raised in New Zealand white rabbits. The antiserum was completely absorbed by the whole antigen molecule but did not adsorb with the synthetic amino acid fragments $1-22$ or $7-28$. This suggests that the VIP antiserum reacts with the whole VIP molecule. The antiserum did not cross-react with peptides structurally related to VIP, such as glucagon, secretin, and GIP, nor with other neuropeptides, including substance $P$, somatostatin and met-enkephalin. Table 2 shows the characteristics of the VIP antisera.

The controls for the immunostain consisted of non-immune rabbit serum which was used as first layer and the fluorescein-conjugated second layer

Table 2 Characteristics of VIP antisera

\begin{tabular}{|c|c|c|c|}
\hline $\begin{array}{l}\text { Method } \\
\text { and antigen }\end{array}$ & $\begin{array}{l}\text { Conjugate } \\
\text { and coupling } \\
\text { reagent }\end{array}$ & Dilution & $\begin{array}{l}\text { Region } \\
\text { specificity }\end{array}$ \\
\hline $\begin{array}{l}\text { Immunocytochemistry, } \\
\text { natural porcine VIP }\end{array}$ & $\begin{array}{l}\text { KLH, } \\
\text { glutaraldehyde }\end{array}$ & $1: 2000$ & $\begin{array}{l}\text { Whole } \\
\text { molecule }\end{array}$ \\
\hline $\begin{array}{l}\text { Radioimmunoassay, } \\
\text { natural porcine VIP }\end{array}$ & $\begin{array}{l}\text { BSA, } \\
\text { carbodiimide }\end{array}$ & $1: 320,000$ & $\begin{array}{l}\text { Mid-portion } \\
\text { to c-terminus }\end{array}$ \\
\hline
\end{tabular}

KLH, keyhole limpet haemocyanin.

BSA, bovine serum albumin. 
was applied alone. For histology, the sections were stained with haematoxylin and eosin.

\section{RADIOIMMUNOASSAY}

Samples were assayed with a radioimmunoassay procedure especially modified and optimised to the small quantities of tissue available and sensitive to changes of $0.4 \mathrm{fmol} /$ assay tube. The VIP assay was developed to pure porcine peptide and the antiserum used was mid-sequence directed. ${ }^{8}$ Immunoreactive peptide concentrations were expressed as $\mathrm{pmol} / \mathrm{mg}$ protein in the biopsy homogenate. Samples of the homogenate were also chromatographed on G-50 Sephadex columns in $0.05 \mathrm{~mol} / 1$ phosphate buffer containing $0.15 \mathrm{~mol} / \mathrm{l}$ $\mathrm{Na}_{2}$ EDTA, $0.15 \mathrm{~mol} / \mathrm{l}$ sodium chloride and $1 \%$ bovine serum albumin, $\mathrm{pH} 7 \cdot 4$. The column eluent was assayed for VIP-immunoreactivity.

Radioimmunoassay measurements of VIP content were examined statistically by a one-way analysis of variance.

\section{Results}

A semi-quantitative method was used to assess the immunocytochemical results. Each biopsy was graded as follows: $1+$, normal number and distribution of VIP nerves; $2+$, increase in the number of VIP nerves; $3+$, increase in the number of VIP nerves and either a concommitant increase in the number of VIP immunoreactive ganglion cells or distortion of individual fibres taking the form of thickening with a greater density of immunostain; $4+$, increase in the number of VIP nerves and ganglion cells with distortion of the fibres and greater degree of immunostaining. The use of non-immune rabbit serum as first layer and the fluorescein conjugated second layer alone gave no immunostaining.

A characteristic pattern of VIP innervation was seen in all the immunostained control biopsies. The fibres were present in mucosa, muscularis mucosae, and submucosa and could be seen singly or in small bundles of a few fibres. Each fibre was typically thin with multiple varicosities and followed a convoluted pathway through the tissue. In the submucosa, groups of ganglion cells were found just under the muscularis mucosae in the submucous (Meissner's) plexus. Some of these showed VIP immunoreactivity. Vasoactive intestinal polypeptide immunoreactive fibres were present in association with the ganglion cells and they appeared to surround both immunoreactive and nonimmunoreactive ganglion cells. All the biopsies from the normal patients were graded as $1+$ or $2+$.

The majority (10 out of 17 ) of the biopsies from the ulcerative colitics showed a similar pattern of VIP innervation to that seen in the controls and, thus, received grades of $1+$ and $2+$. Five biopsies had increased numbers of VIP nerves with some distortion and were graded as $3+$ and two biopsies had gross changes and were therefore graded as $4+$. Histological examination of the tissue showed that all of those with increased VIP innervation had obvious active disease.

No histological abnormalities were found in the rectal tissue from patients with Crohn's disease of proximal bowel. Where rectal disease could be found, the histological changes were not always obviously those associated with Crohn's disease. All of the biopsies from patients with Crohn's disease had increased VIP innervation. Tissue from patients with normal histology was graded as $2+$ and above, while those with rectal involvement showed consistent, gross changes in VIP innervation and received grades of $3+$ and $4+(7$ cases $)$. In the biopsies with the most abnormal VIP innervation, the fibres had essentially the same distribution as those in the normal controls but both fibres and ganglion cells were markedly increased in number and degree of immunostaining. In addition, the fibres were frequently seen in a straightened thickened form, without their characteristic varicosities.

The results of radioimmunoassay of VIP content are shown in Table 3 and Fig. 1. The VIP content of the biopsies from patients with rectal Crohn's disease was found to be more than doubled from the control level of $1.64 \pm 0.39 \mathrm{pmol} / \mathrm{mg}$ protein (mean \pm SEM) to $3.43 \pm 1.24 \mathrm{pmol} / \mathrm{mg}$ protein. A larger statistically significant difference $(p<0.02)$ in VIP content was found between biopsies from patients with non-rectal Crohn's disease, which contained $5.37 \pm 1.23 \mathrm{pmol} / \mathrm{mg}$ protein and the normal controls. Biopsies from ulcerative colitics contained less VIP than the controls, $1.34 \pm 0.37 \mathrm{pmol} / \mathrm{mg}$ protein, but this was not a statistically significant difference. The difference between the content of VIP of the biopsies from colitics and those from

Table 3 Vasoactive intestinal polypeptide content of rectal biopsy homogenates

\begin{tabular}{ll}
\hline & $\begin{array}{l}\text { VIP } \\
(\text { pmol/mg protein } \pm \text { SEM) }\end{array}$ \\
\hline Controls (17) & $1 \cdot 64 \pm 0 \cdot 39$ \\
Ulcerative colitis (19) & $1 \cdot 34 \pm 0 \cdot 37^{*}$ \\
Non-rectal Crohn's (14) & $5 \cdot 37 \pm 1 \cdot 23 \dagger$ \\
Rectal Crohn's (14) & $3 \cdot 43 \pm 1 \cdot 24$ \\
\hline
\end{tabular}

${ }^{*} \mathrm{p}<0.01$ compared with non-rectal Crohn's. $+p<0.02$ compared with controls. 


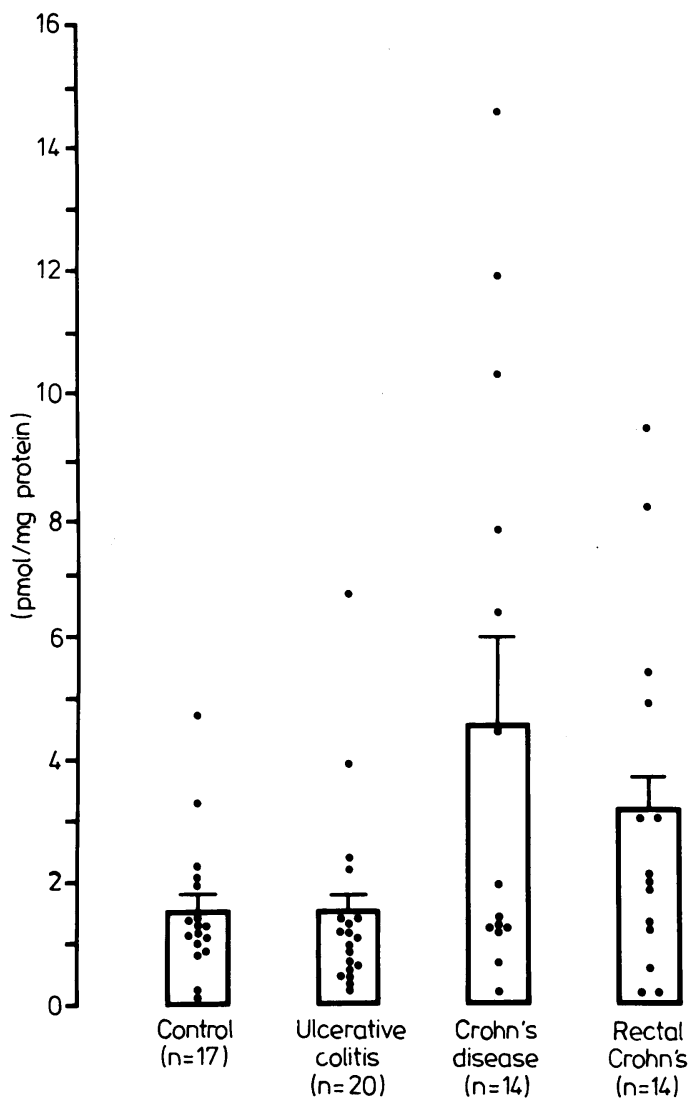

Fig. 1 Tissue VIP content. Individual data points with mean $\pm S E$ are shown for each patient group.

patients with non-rectal Crohn's disease was more significant $(p<0.01)$ than that between the controls and non-rectal Crohn's disease.

On gel permeation chromatography, the VIP immunoreactivity eluted consistently as a single peak in a position similar to that of standard porcine VIP (Fig. 2). A mean of $76 \%$ of total loaded immunoreactivity was recovered from the column.

\section{Discussion}

We have shown in this double blind study that there is a detectable increase in VIP nerves in endoscopic rectal biopsies from patients with Crohn's disease, irrespective of whether or not there is rectal involvement. This means that evidence for the presence of Crohn's disease can be obtained from biopsies which show no pathological changes on conventional histology.

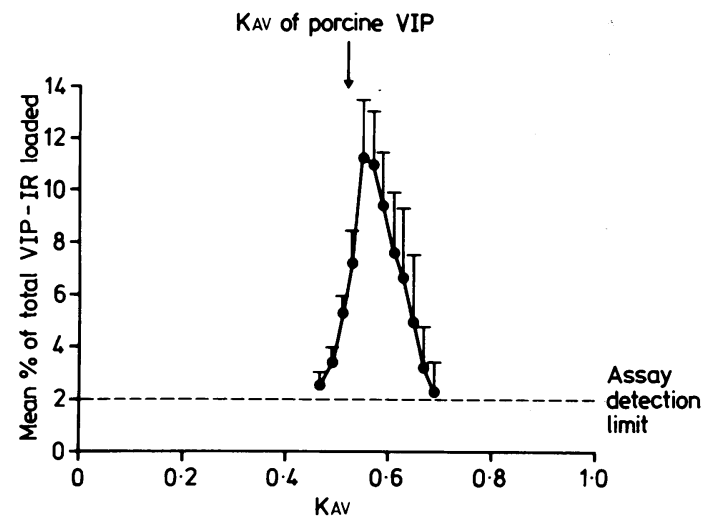

Fig. 2 Chromatography of tissue VIP.VIP \pm SE eluted as single peak in position similar to that of standard porcine VIP. Mean recovery from the column run was $76 \%$.

Comparison of the VIP content of the biopsies shows that there is a statistically significant increase in tissues from patients with no rectal involvement, compared with normal controls. Although there was no significant difference between the VIP content of the biopsies from the two groups of patients with Crohn's disease, the VIP content of the group with rectal Crohn's disease was not significantly increased compared with the normal controls. This may be because of the presence of areas of inflammatory infiltrate and oedema in the diseased biopsies which may dilute the total concentration of VTP in the tissue.

All the biopsies from patients with ulcerative colitis had concentrations of VIP within the normal range. On immunocytochemistry, six cases showed an increase in VIP innervation but examination of the conventional histology in serial sections revealed that these biopsies were clearly from patients with ulcerative colitis and not Crohn's disease. Radioimmunoassay showed no significant difference between the VIP concentrations in the ulcerative colitis tissues and the normal controls. There was, however, a significant difference between VIP content of biopsies from ulcerative colitis and those from patients with non-rectal Crohn's disease, a finding which emphasises the obvious dissimilarity between the two groups.

The significance of VIP nerve hypertrophy in Crohn's disease remains speculative. As for the surgical specimens, ${ }^{5}$ comparison of the changes in VIP innervation with histological and clinical data revealed no absolute correlation. Our findings do not entirely disprove the previous suggestion that the transmural inflammation characteristic of 
Crohn's disease may act as an irritant stimulus for the development of the apparent VIP nerve hypertrophy. An interesting feature of this hypertrophy observed during the studies on surgical specimens is that it is present in histologically normal bowel adjacent to the areas of maximal pathology. The results of the present study support this by showing consistent increases in VIP containing nerves in normal recta from patients with Crohn's disease. This finding suggests that some stimulus exists other than transmural inflammation. Our results, in agreement with previous studies, ${ }^{9-12}$ reveal that the involvement of the gastrointestinal tract in Crohn's disease is more extensive than is revealed by conventional histological methods. These previous studies have included the demonstration of a significant increase in IgM-containing cells ${ }^{10}$ and of certain enzyme activities ${ }^{11} 12$ in apparently uninvolved tissue, as judged by routine histology. It is not possible, on the basis of our current findings to determine whether these alterations are related to the VIP nerve hypertrophy. They may form part of a generalised tissue reaction which may lead to the typical pathological lesion of Crohn's disease.

We are grateful to Ms Rosamund Greensted for secretarial assistance. This work was supported in part by MRC project grants.

\section{References}

1 Makhlouf GM. Role of VIP in the function of the gut. In: Said SI, ed. Vasoactive intestinal polypeptide. New York: Raven Press, 1982: 425-46.
2 Bloom SR, Polak JM, Pearse AGE. Vasoactive intestinal peptide and water diarrhoea syndrome. Lancet 1973; 1: $14-6$.

3 Modlin IM, Bloom SR, Mitchell SJ. Experimental evidence for vasoactive intestinal polypeptide as the cause of the watery diarrhoea syndrome. Gastroenterology 1978; 75: 1051-4.

4 Bishop AE, Ferri G-L, Probert L, Bloom SR, Polak JM. Peptidergic nerves. Scand J Gastroenterol 1982; 17: suppl 71, 43-59.

5 Bishop AE, Polak JM, Bryant MG, Bloom SR, Hamilton S. Abnormalities of vasoactive intestinal polypeptide-containing nerves in Crohn's disease. Gastroenterology 1980; 79: 853-60.

6 Bishop AE, Polak JM, Bloom SR, Pearse AGE. A new universal technique for the immunocytochemical localisation of peptidergic innervation. J Endocrinol 1978; 77: 25-6.

7 Coons AH, Leduc EH, Connolly JM. Studies on antibody production. 1. A method for the histochemical demonstration of specific antibody and its application to the study of the hyperimmune rabbit. J Exp Med 1955; 102: 49-60.

8 Mitchell SJ, Bloom SR. Measurement of fasting and postprandial VIP in man. Gut 1978; 19: 1043-8.

9 Goodman MJ, Skinner JM, Truelove SC. Abnormalities in the apparently normal bowel mucosa in Crohn's disease. Lancet 1976; 1: 275-8.

10 Rosekrans PCM, Meyer CJLM, Van de Wal AM, Cornelisse $\mathrm{CJ}$, Lindeman $\mathrm{J}$. Immunoglobulincontaining cells in inflammatory bowel disease of the colon: a morphometric and immunohistochemical study. Gut 1980; 21: 941-7.

11 Goodman MJ, Kent BW, Truelove SC. Glucosamine synthetase activity of the colonic mucosa in ulcerative colitis and Crohn's disease. Gut 1977; 18: 219-28.

12 O'Morain C, Smethurst P, Levi AJ, Peters TJ. Studies of the organelle pathology in rectal tissue from patients with inflammatory bowel disease. Eur J Clin Invest 1982; 12: 28 . 